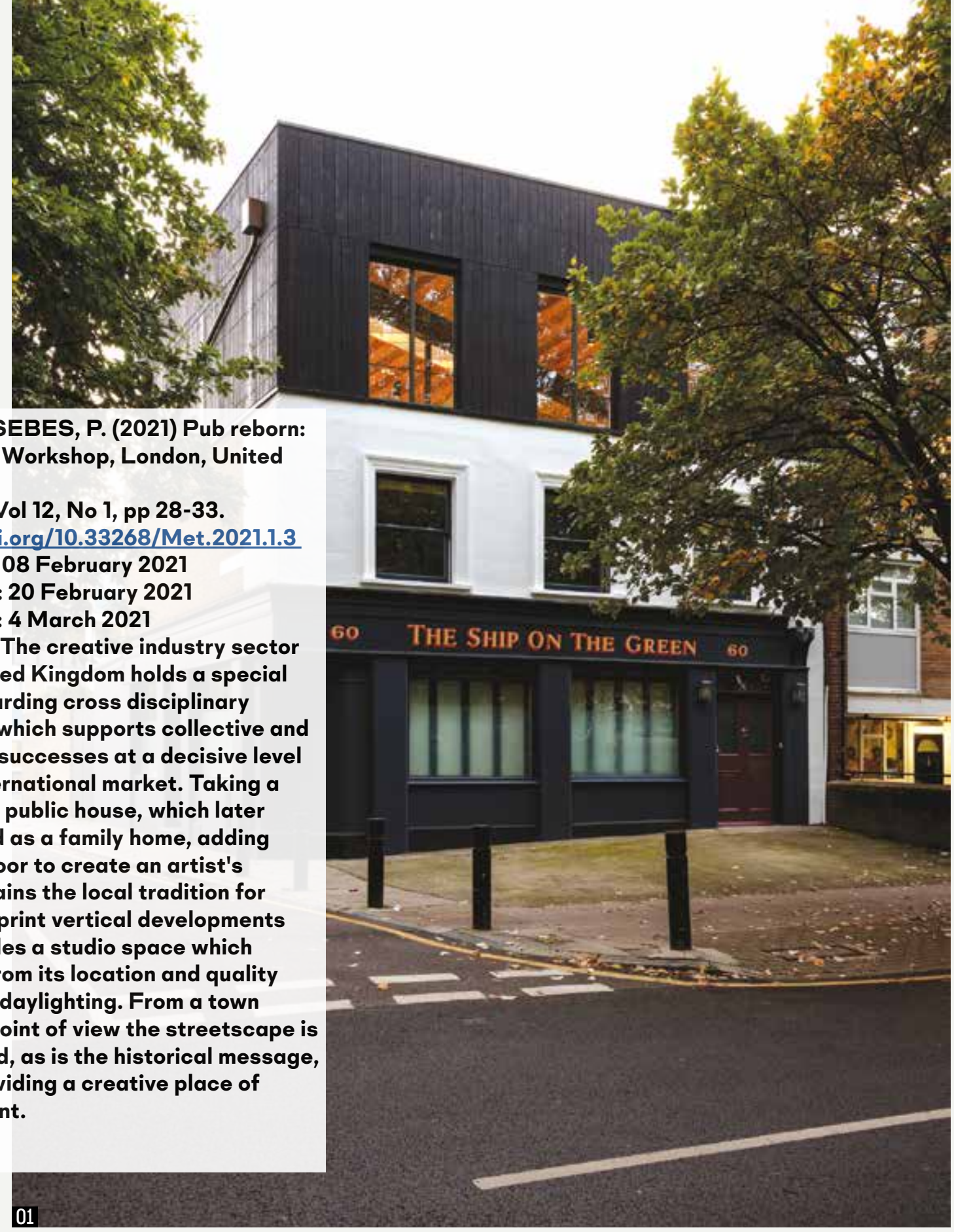

Citation: SEBES, P. (2021) Pub reborn: Sculpture Workshop, London, United Kingdom

Metszet, Vol 12, No 1, pp 28-33.

https://doi.org/10.33268/Met.2021.1.3

Received: 08 February 2021

Accepted: 20 February 2021

Published: 4 March 2021

Abstract: The creative industry sector in the United Kingdom holds a special place regarding cross disciplinary activities which supports collective and individual successes at a decisive level on the international market. Taking a redundant public house, which later functioned as a family home, adding another floor to create an artist's studio retains the local tradition for small footprint vertical developments and provides a studio space which benefits from its location and quality of natural daylighting. From a town planning point of view the streetscape is maintained, as is the historical message, whilst providing a creative place of employment.

\title{
EGY PUB ÚJ ÉLETE
}

\section{SZOBRÁSZMÜTEREM | LONDONBAN}

_Nagy-Britannia fontos gazdasági ágazatának számítanak az összefoglaló néven kreatív iparágnak nevezett legkülönfélébb alkotói tevékenységek. Ebben természetesen a nemzetközi piacon is jelen lévő, nagy létszámú formatervező, divattervező, a filmes látványiparban tevékenykedő múhelyek vagy éppen építészirodák az igazán meghatározóak, de az egyéni érvényesülés sem lehetetlen. 


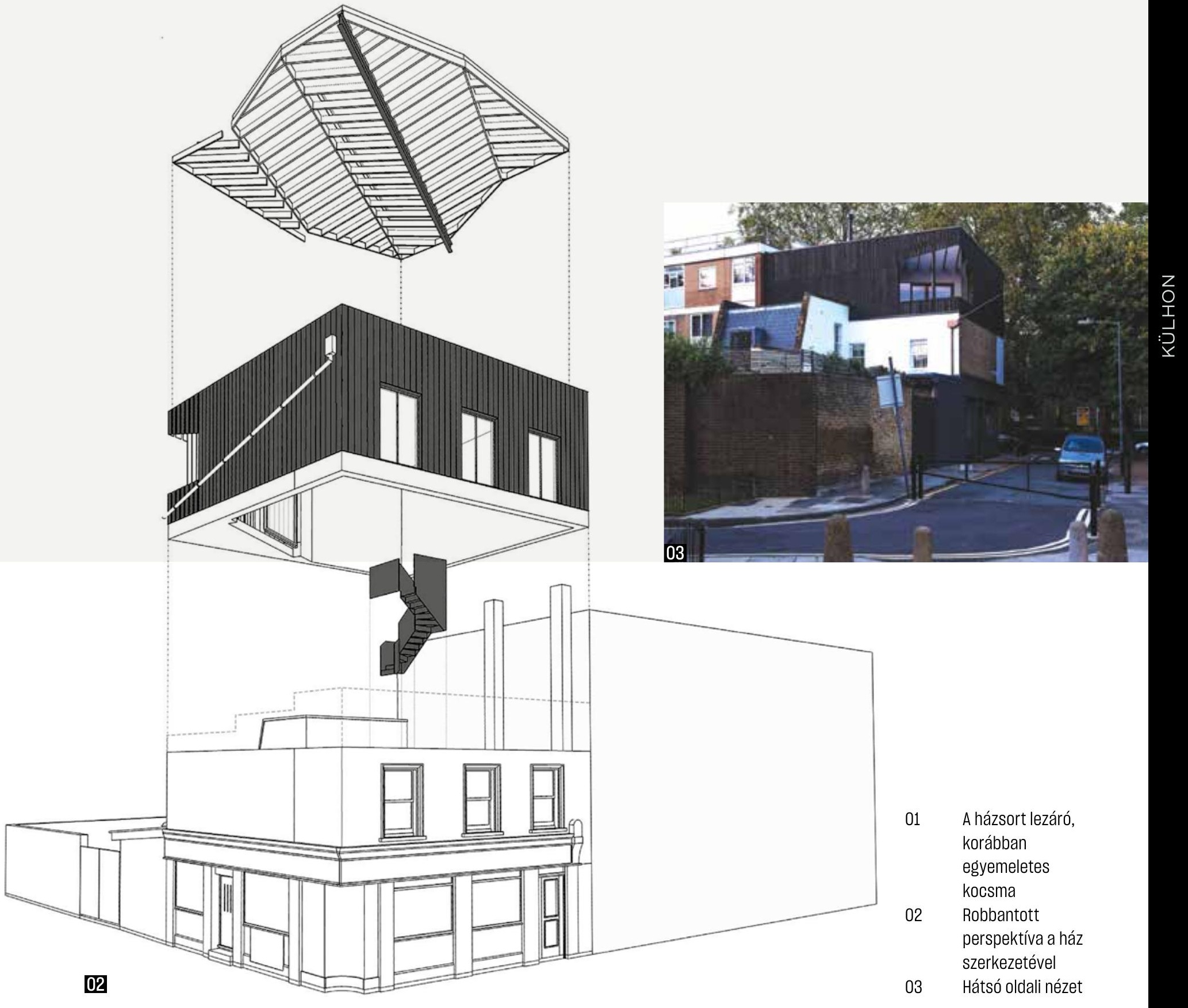

ÉPÍTÉSZ | ARCHITECT

Martin Edwards
FOTÓ | PHOTO

Max Creasy
SZERZŐ | AUTHOR

Sebes Péter
_ A megfelelő számú kreatív elme kineveléséből az oktatási intézmények alaposan kiveszik a részüket, így szinte alig akad olyan középiskola vagy felsőoktatási intézmény, amelyik ne kínálna a művészetek valamelyik ágába tartozó képzést. A cél nem kifejezetten a művészelit képzése. A rendszer sokkal inkább abból indul ki, hogy az alkotás élményét megtapasztaló, egy adott művészeti tevékenység alapjait elsajátító fiatal tehetség kibontakozását segíthetik a változatos munkalehetőségek és a müvészetekre nyitott társadalom.
Míg alkalmazotti formában a nagy cégek mellett számtalan startup vállalkozás is kínál lehetőségeket, az egyéni bemutatkozás elősegítésére a világhírü múzeumoktól és színházaktól a teljesen névtelen „sarki galériáig” és eldugott alapítványi színpadokig megszámlálhatatlan lehetőséget felsorakoztató, mindenre nyitott kiállító- és előadóhelyek sora viszi közel a művészeti terméket a közönséghez.

_ Míg a nagyobb kreatív vállalkozások a legkorszerübb feltételeket biztosítják új ötletek kidolgozásához 


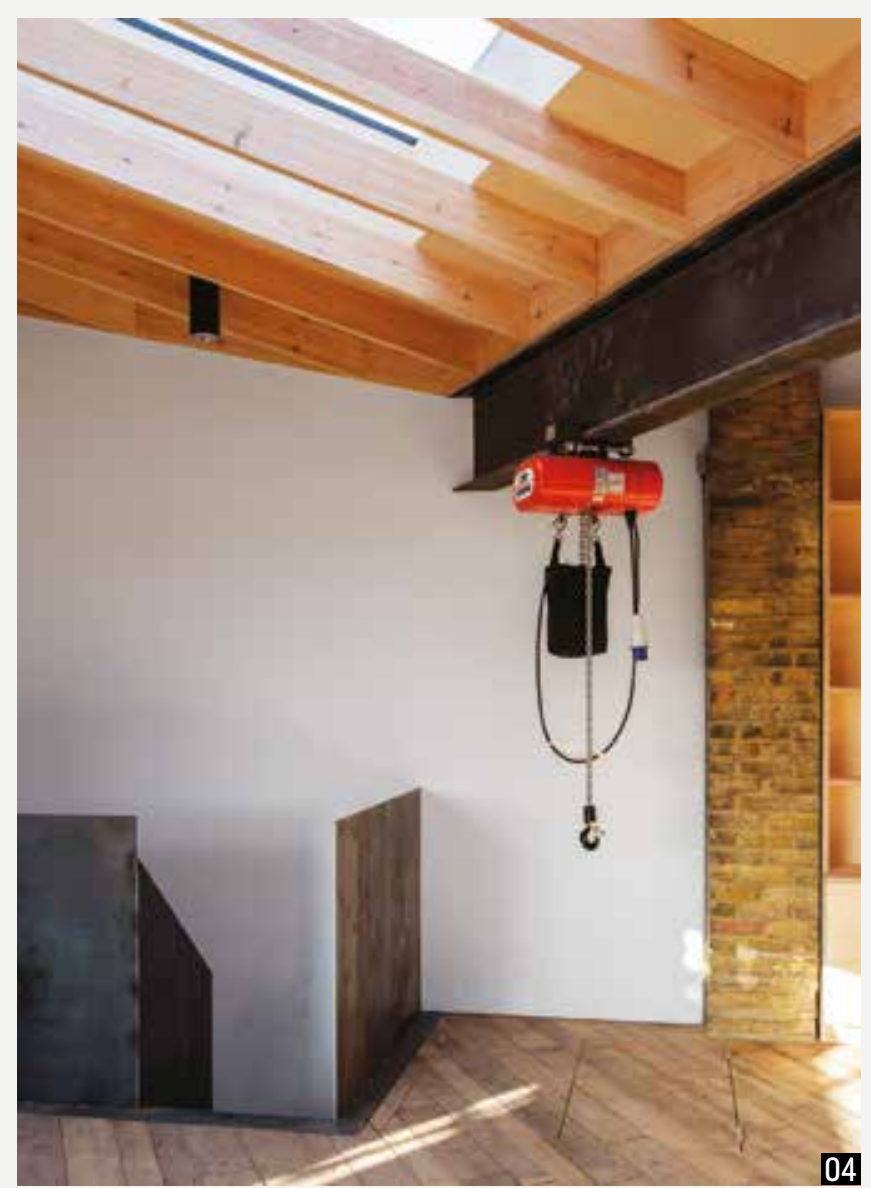

fizetett munkavállalóiknak, azoknak, akik inkább a maguk útját járják, megfelelő alkotói mühelyt kell találniuk munkájukhoz. Nagyvárosi környezetben az egyik kézenfekvő megoldás egy volt raktár vagy műhely bérbe vétele, ezzel azonban jelentős bizonytalansági tényezőt kénytelen bevállalni a művész, hiszen az egykori ipari épületek telkeire vadásznak az ingatlanfejlesztők, és ahogyan azt egy kreatív néhány éve be is mutatta a város lakóinak egy viaszházzal, [I] szemmel látható tempóban tűnnek el a város régi épületei, elsősorban éppen a termelés, alkotás helyszínei.

_ Hosszú távú megoldást csak saját tulajdonú müterem jelent, ami komoly tőkebefektetéssel jár; főleg Londonban, a brit művészeti élet központjában ilyesmit csak már befutott múvész engedhet meg magának. Mivel a város belső részeiben új ház építésére alkalmas telket szinte lehetetlen találni, érdemes az újrahasznosítás ötletét megfontolni, például egy funkcióját vesztett, de mérete miatt a fejlesztők érdeklődését elkerülő épületet, akár egy elhagyott kocsmát keresni.

_ Az angol kocsma története közel kétezer évre, a római kori tavernák koráig tekint vissza. A pub neve a „public house”, nyilvános ház kifejezésből ered, amelyet a magyar nyelvben használatos jelentésével ellentétben inkább közösségi házként kell felfogni. A pub a mai napig az egyik legnépszerübb szórakozási, kapcsolattartási forma a szigetországban, bár számuk az utóbbi évtizedekben kitartóan csökkent. Ezek az épületek az ital- és ételfelszolgálás mellett szálláshellyel is rendelkeztek, és a tulajdonos is bennük lakott. Így ha

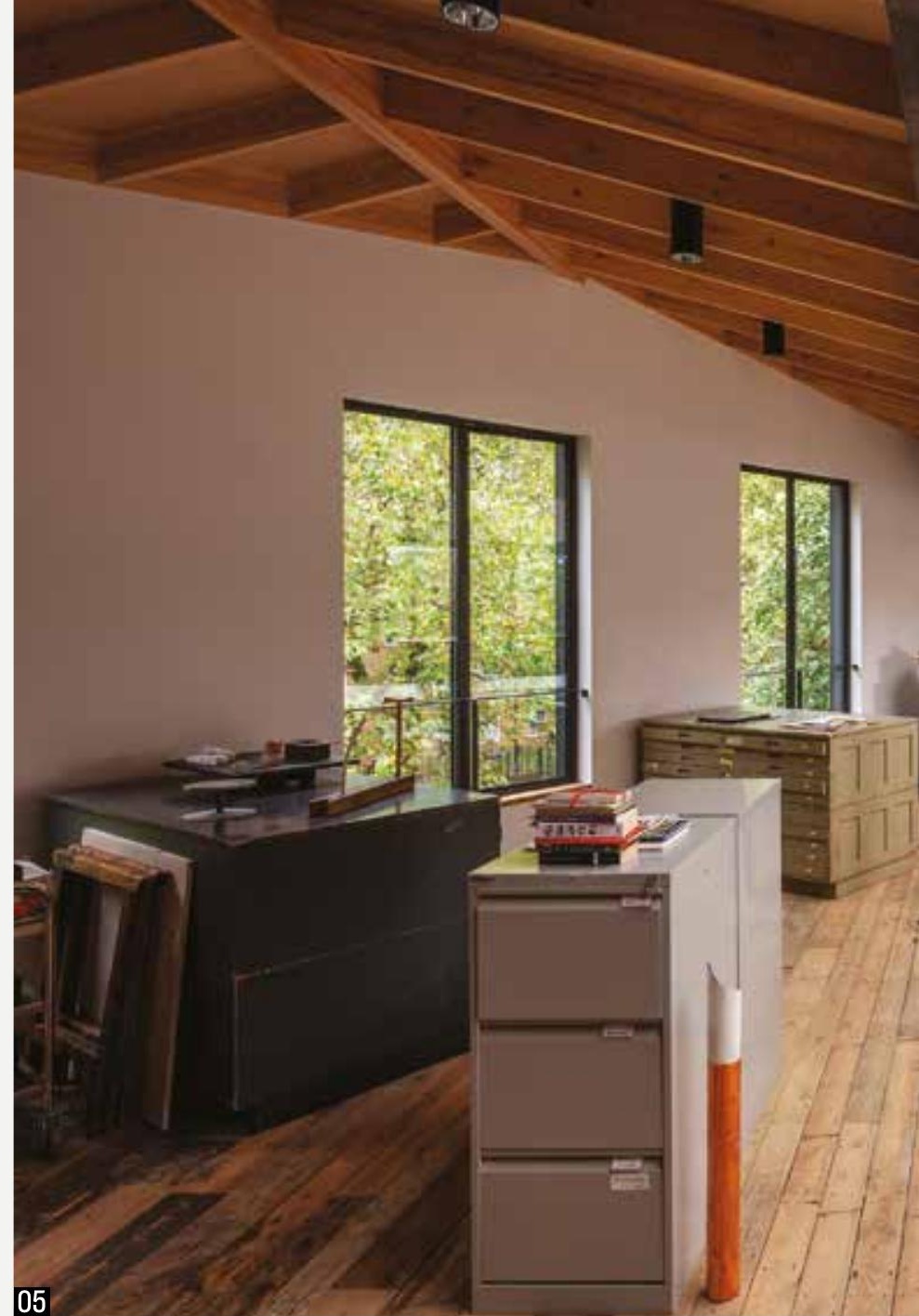

egy kocsma bezár, az egész épület számára kell új hasznosítási módot találni. Bár bontásukra engedélyt kapni nem lehetetlen, az önkormányzatok többnyire olyan megoldást látnak szívesen, amivel meg lehet menteni nemcsak az egykor az utca többnyire legjelentősebb épületét, hanem azt a halvány reménysugarat is, hogy valamikor visszanyerheti egykori közösségszervező szerepét. Tehát az értékmentő újrahasznosítás jó pont lehet az engedélyezés folyamatában. Ennek köszönhetően sokfelé fel lehet lelni a városban a korábbi századok egy-egy, múltját büszkén vállaló, magányos tanúját. _ Az ismert londoni szobrász az I8IO-es évek végéről származó, Kelet-London városképileg védett területén található háza eredetileg kocsmaként müködött. [2] A „Ship on the Green”-ben az elmúlt negyed században már nem mértek sört. Az idő közbeni átalakítások eredményeként kissé átformálódott épület eredetileg egy György korabeli házsor végét képezte egy lineáris zöldfelület, a Stepney Green középen fasoros széles sétánya mentén.

_ A terület a második világháborúban súlyosan megrongálódott, csak néhány épület maradt fenn, a szomszédos házak többségét a háború után lebontották, helyettük új, modernista lakóházakat húztak fel az ötvenes évek stílusirányzatának megfelelő homlokzati tagolással, de illeszkedve a már kialakult párkánymagassághoz. A kocsma is a háborúban veszítette el teljes legfelső emeletét, de alsó két szintjét helyreállították, és egészen az 1990-es évek közepéig működött, amikor is eladták, majd később lakóházzá alakították át. 

A | Meglévő udvar
B | Újudvari múterem
C | Meglévő konyha
D | Felújított földszinti zuhanyzó
E | Új bejárati folyosó
F | Meglévő nappali

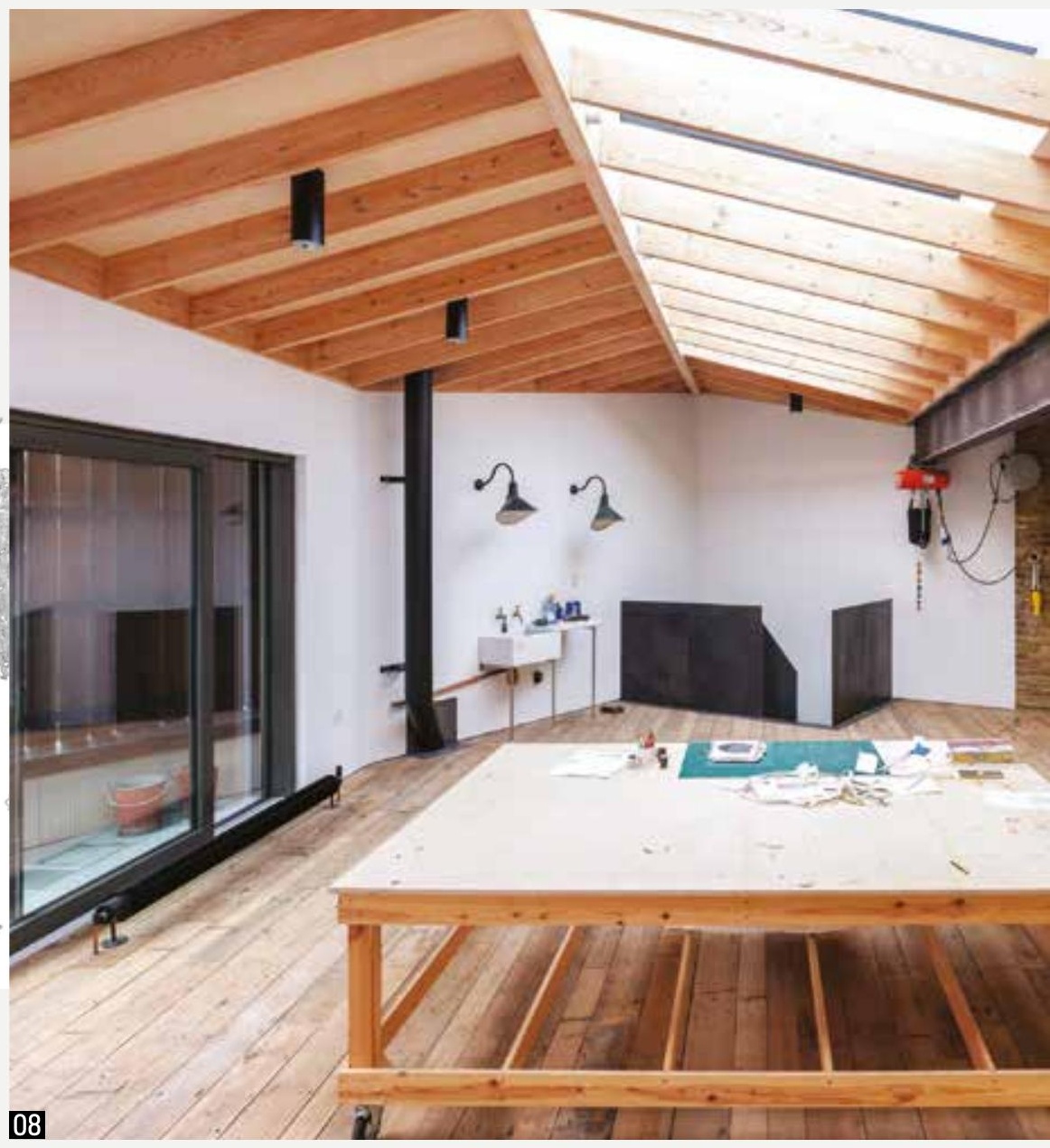

Földszinti alaprajz

Az átlós elrendezésű emelet

Az új tetőszerkezet metszete

Tető csomópont
— Martin Edwards égetett és olajozott felületkezeléssel megdolgozott, hőkezelt kőrisdeszkát választott a kettős kontinuitás eléréséhez. Az égetéssel nyert elszenesedett felület az épület életciklusa alatt bekövetkezett múltbeli eseményekre, így a háborús sérülésekre is erős utalás, de határozott karakterével a középső szint téglaburkolatát és vakolt falfelületeit is tagolja, ami a modernista szomszédok ritmusos homlokzati foltjátékára is reagál. Az eredeti oldalsó homlokzat egyik legmeghatározóbb eleme volt egy ferdén keresztbe lefutó esővízcső, amely a második emeleti attika csatornából vezetett a hátsó oldali földszinti üstig. Ezt eleveníti fel az új réz esővízcső, mely követi az eredeti grafikát, absztrakt módon vetíti ki a homlokzatra a megfiatalodott épület belsejében végbement átrendeződést.

_ A legfelső emeleti új, északra néző utcai ablakok a lineáris park fáinak lombkoronái látványával helyezik természeti környezetbe az alkotóhelyet. A homlokzati asztalos szerkezetek színét úgy választották meg, hogy sötét tónusukkal közelebb kerüljenek a késő György és Viktória korabeli színvilághoz, amely egyébként a mai napig töretlen népszerűségnek örvend Londonban.

_ Favázas hőszigetelt könnyűszerkezettel oldották meg a ráépítést, amely kisebb többletterhelést ad át az eredeti szerkezetre; a szabálytalan formájú tetőt acélkoszorú fogja körbe. Kettős nyereg fa tetőszerkezete belülről nyitott, a középső vápa egy acél mestergerendára támaszkodik. Darupályaként is szolgál a gerenda, a rá helyezett emelőcsörlővel kiegészített futómacska a nehéz anyagok vagy az elkészült alkotás mozgatását teszi lehetővé egy födémbe rejtett nyílással a szintek között.

_ A belső térben használt anyagok nemcsak visszatükrözik a szobrászmüterem ipari jellegét, hanem az épület korábbi életére, korára is tartalmaznak utalásokat. Padlója a munkálatok során a korábbi tetőfedések rétegei alatt talált alátét deszkázatból lett újrahasznosítva. Az első emeleten átalakított közlekedőből új, kezeletlen hengerelt acéllemezből készített lépcső vezet fel a stúdióba.

— Kibővítették a földszinten lévő hátsó szárnyat is, egy új vendéglakrész számára. A földszinti bővítmény egy korábbi kiegészítéshez illeszkedő színű, bontásból nyert téglából épült, belülről hőszigetelve, hogy megfeleljen a mai hőtechnikai elvárásoknak. Az eredeti üvegezett faajtókat kijavították és az újonnan felhúzott falba építették be, a korábban az udvarban lévő pala kőlapokat pedig padlóburkolatként hasznosították újra. Az új, beépített nyírfa rétegelt lemezből készült fal tárolóhellyel, dolgozósarokkal és rejtett, lehajtható ággyal biztosít kényelmes helyet a vendégek számára. Lapos tetejét olyan vadvirág fajok keverékével ültették be, melyek a helyi városi környezetben is megtalálhatók. _ A müvészet számos alkotó számára életformát jelent, mely nehezen szorítható be napi rutinba ágyazott munkaórákba. Az alkotás komplex folyamatában szükség van meditációt, kísérletezést, kapcsolattartást és bemutatkozást támogató terekre is. Bár az új mütermet 

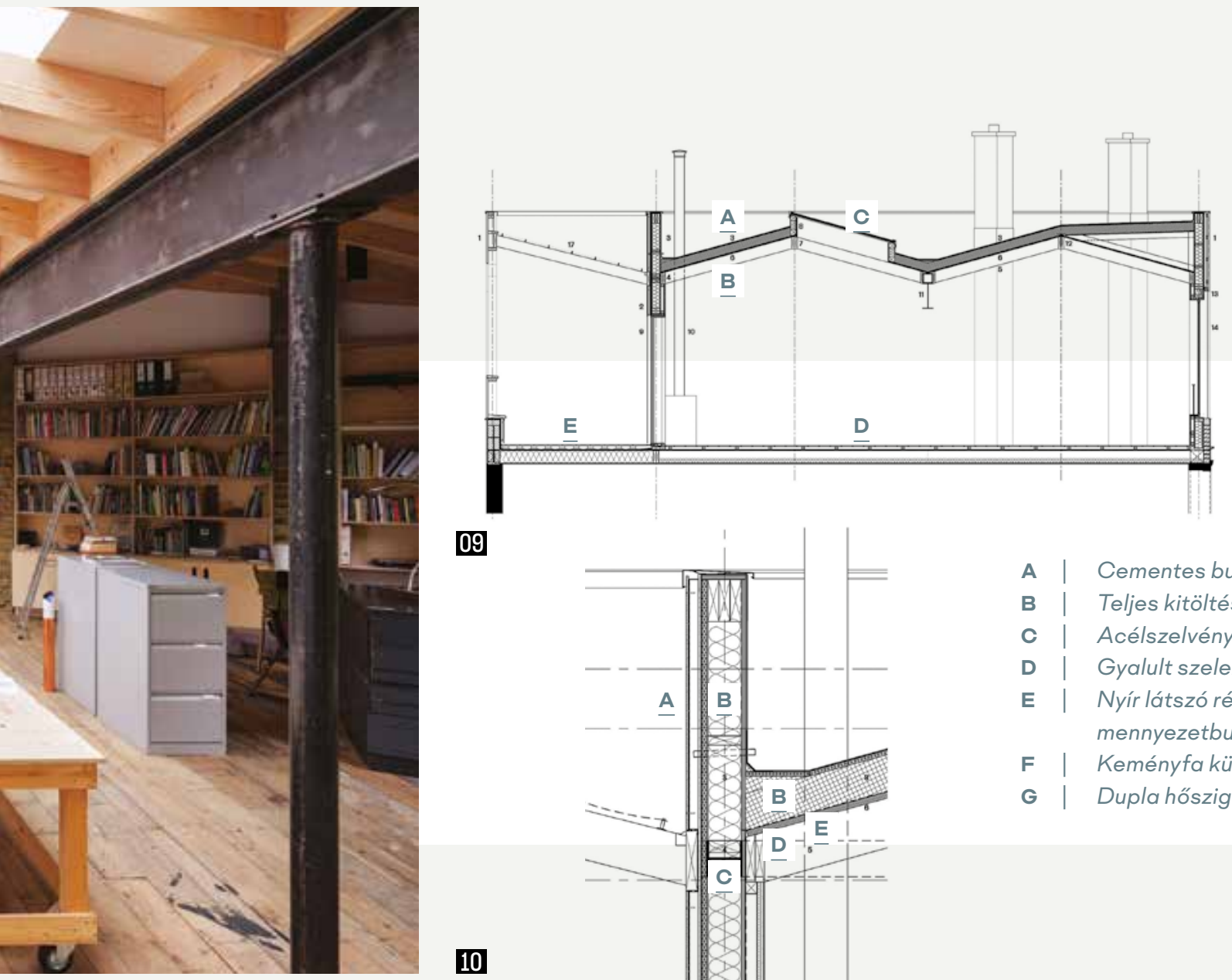
A | Teljes
hőszigetelés
kitöltés

a gerendák között

B | Gyalult

szelemenek

rejtett rögzítéssel

C | Multipane diffúz

fényú felülvilágító

hőszigetelő

kerettel

D | Bontott fából

készített padló

E Kö teraszburkolat

09

10

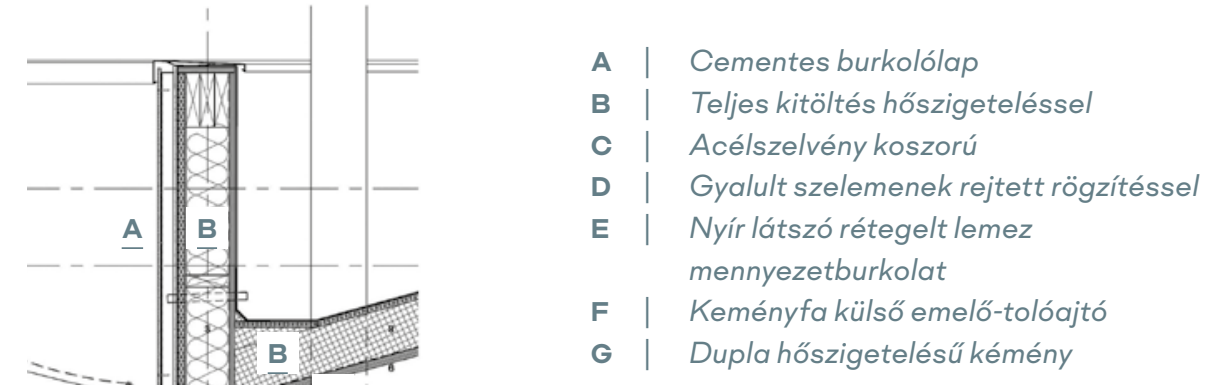

láthatóan kiválóan összedolgoztak a megfelelő eredmény elérése érdekében. Úgy hoztak létre egy korszerű alkotómühelyt, hogy teljes mértékben elfogadták az adottságokat, és készek voltak úgy új életet vinni a 19. századi épületbe, hogy abból minden lehetséges elemet újrahasznosítottak. Ezzel a megközelítéssel nemcsak környezettudatos és gazdaságos, de ugyanakkor egyedi esztétikát magában hordozó új helyi értéket hoztak létre a kétszáz év történelmét megélt, védett utcaképben. nem utolsósorban a megrendelő nyitottságán múlik, hogy milyen megoldásokkal lehet minimalizálni a környezetre káros kibocsátás mértékét. A projekt alkotói

egyetlen tisztán funkcionális térként alakították ki, az egész épület az alkotást támogató informatív terek rendszere, melyhez kiváló alapot biztosítanak az egykori fogadó tágas terei.

nyezettudatos elveket a tervezés hétköznapi gyakorlatába integrálni. Míg nagyobb projektek esetében fenntarthatósági minősítő rendszerek teszik ezt mérhetővé, kisebb projekteknél a tervező kreativitásán és

\section{IRODALOM / REFERENCES}

[1] Sebes, Péter: „Olvadó ház Londonban”, Tervlap, 2014-11-10, hozzáférhető: <https://tervlap.hu/cikk-nezet/olvado-haz-londonban> [utolsó belépés: 2021-02-12].

[2] Pub Wiki / Ship, 64 Stepney Green, Mile End E1 [honlap], hozzáférhető: <https://pubwiki.co.uk/LondonPubs/MileEnd/ShipStepney.shtml> [utolsó belépés: 2021-02-12].

[3] A London Inheritance / New Deal For East London - Stepney Green [honlap], hozzáférhető: <https://alondoninheritance.com/london-buildings/ new-deal-for-east-Iondon-stepney-green/> [utolsó belépés: 2021-02-12].

[4] Rattner, Donald M: My Creative Space: How to Design Your Home to Stimulate Ideas and Spark Innovation, Skyhorse Publishing, New York 2019.

ÉPÍTÉSZ: Martin Edwards Architects, Martin Edwards I SZERKEZETTERVEZŐ: Conisbee | KIVITELEZŐ: Adam Lloyd Construction | MÜTEREM TERÜLETE: 108 M² | ÉPÍTÉS ÉVE: 2020 | FOTÓK: Max Creasy | FOTÓ: SHIP ON THE GREEN ÁTÉPÍTÉS ELŐTT: HTTPS://COMMONS.WIKIMEDIA.ORG/ WIKI/FILE:SHIP_ON_THE_GREEN,_STEPNEY,_E1_(3368042971).JPG EWAN MUNRO (WIKIMEDIA COMMONS) 